\section{Intraoperative Neurophysiological Monitoring During Surgery for Tethered Cord Syndrome}

\section{Gergin Omurilik Sendromu Cerrahisinde Intraoperatif Nörofizyolojik Monitörizasyon}

\begin{abstract}
AIM: The tethered cord syndrome refers to a variety of lesions that can cause the conus medullaris to be low-lying or incapable of movement within the spinal canal. Permanent or temporary neurological complications were reported following surgical release. In this report, peri- and postoperative results in cases with tethered cord syndrome that were followed by multimodal intraoperative neurophysiological monitoring (MIONM) methods are presented.

MATERIAL and METHODS: An IONM system (Nicolet CR Endeavor) was used for monitoring during tethered cord surgery. Somatosensory evoked potentials (SEPs), motor evoked potentials (MEPs), direct nerve root/rootlet stimulation, free-run electromyography (EMG) and F-waves were used during tethered cord surgery of 10 cases to prevent possible nerve injuries.

RESULTS: MEP and SEP recordings did not change in any of the cases during surgery. The nervous tissue was identified and differentiated from connective tissue in three cases when motor responses were elicited with direct stimulation of nerve roots. None of the cases had neurological deficits following the operation. CONCLUSION: Direct nerve root/rootlet stimulation should be one of the components of MIONM during surgery for tethered cord syndrome to prevent postoperative neurological deficits.

KEYWORDS: Tethered cord syndrome, Neurophysiological monitoring, Evoked potentials, Spinal cord
\end{abstract}

\section{ÖZ}

AMAÇ: Gergin omurilik sendromu, konus medullarisin aşağı yerleşmesine veya spinal kanal içinde hareket etmesine engel olan çeşitli lezyonları tanımlar. Cerrahi serbestleştirme sonrası kalıcı ya da geçici nörolojik komplikasyonlar gözlenebilir. $\mathrm{Bu}$ çalışmada, tethered kord sendromu cerrahisi sırasında multimodal intraoperatif monitörizasyon (MIONM) yöntemleri ile izlenen olgularının sonuçları sunulmaktadır.

YÖNTEM ve GEREÇ: Gergin omurilik sendromlu olguların ameliyatlarının izlemlerinde İONM cihazı (Nicolet CR Endeavor) kullanıldı. MİONMkapsamında 10 tethered kord sendromlu olgunun ameliyatları sırasında olası sinir hasarını engellemek için somatosensoriyel uyarılmış potansiyeller (SUP), motor uyarılmış potansiyeller (MUP), direkt sinir kökü uyarımı yanıtları, sürekli elektromiyografi, ve F-yanitları izlendi.

BULGULAR: Gergin omurilik sendromu nedeniyle opere edilen olguların hiçbirinde MUP ve SUP kayıtlarında ameliyat sırasında farklılık gözlenmemiştir. Üç olguda sinir dokularının konnektif dokulardan ayrımı amacıyla yapılan direkt uyarım ile motor yanıtlar elde edilmesi üzerine ilgili sinir dokuları korunmuştur. Olguların hiçbirinde ameliyat sonrasında nörolojik kayıp gözlenmemiştir.

SONUÇ: Gergin omurilik sendromu cerrahisinde ameliyat sonrası gelişebilecek nörolojik kayıpları engellemek için direkt sinir uyarımı multimodal intraoperatif nörofizyolojik monitörizasyonun bir parçası olarak kullanılmalıdır.

ANAHTAR SÖZCÜKLER: Gergin omurilik sendromu, Nörofizyolojik monitörizasyon, Uyarılmış potansiyeller, Omurilik

\author{
Mehmet BEYAZOVA ${ }^{1}$ \\ Murat ZINNUROGLU² \\ Hakan EMMEZ ${ }^{3}$ \\ Kadir KAYA ${ }^{4}$ \\ H. Zerrin OZKOSE ${ }^{5}$ \\ M. Kemali BAYKANER ${ }^{6}$ \\ Zeynep ERDEN7 \\ Nurdan ORUCOGLU ${ }^{8}$ \\ Gokhan Tuna OZTURK ${ }^{9}$ \\ Zeynep ERDOGAN ${ }^{10}$ \\ 1,2,7,8,9,10 Gazi University, Faculty of \\ Medicine, Department of Physical \\ Medicine and Rehabilitation, \\ Ankara, Turkey \\ 3,6 Gazi University, Faculty of \\ Medicine, Department of \\ Neurosurgery, Ankara, Turkey \\ 4,5 Gazi University, Faculty of \\ Medicine, Department of \\ Anesthesiology and Reanimation, \\ Ankara, Turkey
}

Received : 02.06.2010

Accepted : 03.08.2010

Correspondence address:

Mehmet BEYAZOVA

E-mail: mbeyazova@gmail.com 


\section{INTRODUCTION}

The tethered cord syndrome (TCS) is an uncommon disease caused by an abnormal stretching of the spinal cord, and it has a reported incidence of 0.05 to 0.25 per 1000 births $(4,13)$. Untethering of the tight filum terminale may be a treatment option. Permanent neurological complications were reported in about $4.5 \%$ of patients $(2,9)$, and this was as high as $10.9 \%$ (11) when transient complications were taken into account (12). The conus medullaris and cauda equina, which supply the sensorimotor functions of the lower extremities and control of bladder and bowel, may be injured during microsurgery of the tethered cord. The anatomy may be variable and differentiation of the nervous tissue from a filum terminale may be extremely difficult due to the arachnoidal scar tissue or the similar appearance of the neural and connective tissue in some cases. Intraoperative neurophysiological monitoring (IONM) may help to protect the functional nervous tissue and prevent postoperative neurological deficits $(3,5,8,10)$. However, there is no evident consensus on the exact methods of multimodal (M)IONM that should be used during surgery for TCS (12).

In this report, the peri- and postoperative results of cases with TCS who were monitored by MIONM methods are presented.

\section{MATERIAL and METHODS}

Multimodal intraoperative neurophysiological monitoring (MIONM) was conducted during surgery for 10 cases with TCS who were admitted to the Pediatric Neurosurgery Unit between December 2008 and March 2010.

\section{Monitoring equipment}

Nicolet Endeavor $\mathrm{CR}^{\mathrm{TM}}$ (Viasys Healthcare, Nicolet Biomedical) system was used for IONM. Motor evoked potentials (MEPs) were assessed for the motor pathways while somatosensory evoked potentials (SEPs) were used for sensory pathways. In addition, free-run electromyography (EMG), direct nerve root/rootlet stimulation and F-waves were monitored. A specific template with various panels was developed for TCS surgery to manage monitoring of multiple panels concurrently. The surgical procedure was observed by all the staff through the camera and screening system of the operating room.

\section{Evoked potentials}

Somatosensory evoked potentials (SEPs) were recorded from the scalp on $\mathrm{C}^{\prime}-\mathrm{FPz}$ and $\mathrm{C}^{\prime}{ }^{\prime}-\mathrm{FPz}$ montages via the corkscrew electrodes (corkscrew, Viasys 019-425100) or subdermal needle electrodes (stainless steel, Viasys 698-621700) by stimulating median or ulnar nerves bilaterally with self-adhesive surface electrodes (disk, Viasys 019-415000). In the lower extremities, bilateral tibial nerves were stimulated by surface electrodes, and the SEPs were recorded from inion-FPz and FZ'-FPz via corkscrew electrode montages (Figure 1). The sensitivity was set to $0.5 \mu \mathrm{V} / \mathrm{mm}$ and the sweep speed was 100 msec. Filter settings were adjusted as $100-300 \mathrm{~Hz}$. The stimulus frequency was $1.7 \mathrm{~Hz}$, and the duration was $500 \mu \mathrm{s}$ for tibial nerve and $300 \mu$ s for the median nerve. The mean stimulus strength was 25 and $10 \mathrm{~mA}$ for tibial and median nerves, respectively.

Motor evoked potentials (MEPs) were recorded by subdermal needle electrodes (stainless steel, Viasys 698-621700) from abductor pollicis brevis or usually from bilateral abductor digiti quinti due to the intraarterial interventions to the radial artery at the wrist. In the lower extremities, MEPs were recorded from bilateral adductor magnus, vastus lateralis, tibialis anterior, abductor hallucis muscles and external anal sphincter (EAS) involving L2-S5 myotomes. Stimuli were applied by corkscrew electrodes from M3-Mz6 and M4-Mz6 for the left and right motor cortex, respectively (Figure 1). The duration of the stimulus was $1000 \mu$ s and the maximum intensity was $400 \mathrm{~V}$. The frequency of the stimuli including five consecutive train stimuli was $250 \mathrm{~Hz}$, and the filters were set to 30 and $500 \mathrm{~Hz}$.

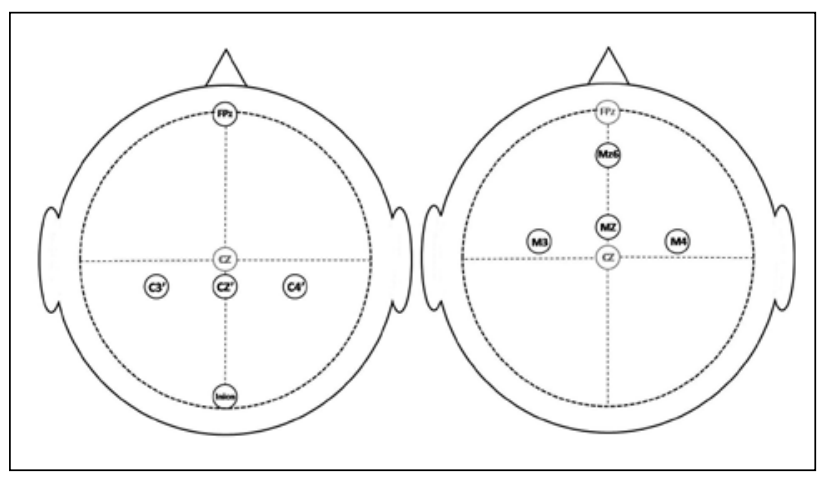

Figure 1: Electrode placement for somatosensory and motor evoked potentials. 


\section{Free-run EMG}

Both visual and audio signals of free-running EMG were monitored in addition to the direct nerve root/ rootlet stimulation and the MEP and SEP recordings. The sensitivity was set to $7 \mu \mathrm{V} / \mathrm{mm}$ and sweep speed was 2 seconds. The filters were adjusted to $10 \mathrm{~Hz}$ and $1.5 \mathrm{kHz}$. Free-run EMG was monitored intermittently due to the interference during the cauterization.

\section{F-wave}

The sensitivity was $20 \mu \mathrm{V} / \mathrm{mm}$ and the sweep speed was $100 \mathrm{~ms}$. The duration of the stimulus was $500 \mu$ s with a frequency of $1.1 \mathrm{~Hz}$, and the maximum intensity was $50 \mathrm{~mA}$ for the posterior tibial nerve.

\section{Direct nerve root/rootlet stimulation}

The tissues suspected to be of nervous structure were stimulated by bipolar stimulator (straight bipolar stimulating probe, Viasys 900X143) and motor responses were recorded. The stimulus duration was $0.1 \mathrm{msec}$ and the maximum stimulus intensity was 5 $\mathrm{mA}$.

\section{Monitoring by a Foley catheter}

In one case, the pressure changes of the detrusor muscle were monitored using a Foley catheter. The functions of the associated nerve root/rootlets were monitored indirectly by the observation of the level of urine inside the tube attached to the Foley catheter (1).

\section{Assessment of the patients}

All cases were evaluated the day before the surgery by the anesthesia and neurophysiological monitoring staff. Written informed consent was obtained from the patients or parents after they were fully informed about the process. Baseline MEPs and SEPs were recorded in each case prior to surgery, and the monitoring was conducted according to the baseline recordings. Recordings were repeated regularly during the surgery and when requested by the surgery team.

\section{Anesthesia}

Anesthesia was started following the monitoring of blood pressure, peripheral oxygen saturation and the ECG. Bolus propophol of $2 \mathrm{mg} / \mathrm{kg}$ was administered after the initiation of Remiphentanyl 0.2 $\mu \mathrm{g} / \mathrm{kg} / \mathrm{min}$ infusion. $100 \% \mathrm{O} 2$ was delivered via face mask or laryngeal mask. The electrodes were placed and the baseline recordings were obtained after the placement of the arterial line and the central venous catheter. $0.5 \mathrm{mg} / \mathrm{kg}$ Atracurium $\left(\right.$ Tracium $\left.^{\mathrm{R}}\right)$, which is a short-acting myorelaxant, was administered following the baseline recordings. The patient was intubated and the cuff was inflated by $2 \%$ lidocaine. Muscle relaxants were not administered afterwards. The anesthesia was continued with total intravenous anesthesia (TIVA) with respect to the cardiovascular parameters (remiphentanyl 0.1-0.2 $\mu \mathrm{g} / \mathrm{kg} / \mathrm{min}$ and propophol $8-6 \mathrm{mg} / \mathrm{kg} /$ hour). Induction of bolus doses of remiphentanyl and propophol was avoided. Mechanical ventilation with air-oxygen mixtures was performed with respect to the end-tidal $\mathrm{CO}_{2^{\prime}}$ which was maintained between 30 and $35 \mathrm{mmHg}$. Hypotensive anesthesia was performed to maintain the arterial blood pressure between 55 and 60 mmHg.

\section{RESULTS}

Baseline MEP and SEP recordings of 10 cases with TCS did not change during the surgery. The clinical and neurophysiological follow-up characteristics of the patients are presented in Table I. Two patients had mild distal paraparesis and three patients presented with neurogenic bladder preoperatively (Table I). In three cases, nerve tissue was identified when motor responses were elicited by direct stimulation thereby differentiating the nervous tissue from connective tissue. In one of the three cases (case number 3, Table I), the nervous tissue was identified to be underneath the connective tissue by means of the elicited motor response (Figure 2, 3). In two cases, motor responses were in the ipsilateral abductor hallucis muscle (case numbers 1 and 3, Table I), and in one case motor responses were recorded from the ipsilateral tibialis anterior and peroneus longus muscles (case number 10, Table I) by direct stimulation. In these cases, the findings were evaluated together with the surgical staff and the functional nervous tissues were protected. The connective tissue was released when there was no motor response by direct stimulation. In two cases we could not manage to record MEP and SEPs. In one of the two cases (case number 2, Table I), inhalation gas anesthetics were used instead of TIVA. In the other case (case number 6, Table I), there were technical problems related with the electrode montage. In one case, temporary discharges were noted in free-run EMG (case number 3, Table I). No F-wave abnormalities were detected in any of the cases. In all of the cases, there were no neurogenic deficits following the surgery, and the physical examination was compatible with the intraoperative neurophysiological findings. 
Table I: Demographic Characteristics and Clinical and Neurophysiological Follow-up Results of Patients

\begin{tabular}{|c|c|c|c|c|c|c|}
\hline & $\begin{array}{c}\text { Age } \\
\text { (years) }\end{array}$ & $\begin{array}{c}\text { Co-existing } \\
\text { malformations }\end{array}$ & $\begin{array}{c}\text { Preoperative } \\
\text { neurological } \\
\text { deficit }\end{array}$ & $\begin{array}{c}\text { Monitoring } \\
\text { success }\end{array}$ & $\begin{array}{c}\text { Post- } \\
\text { operative } \\
\text { deficit }\end{array}$ & $\begin{array}{c}\text { Motor responses } \\
\text { to direct nerve } \\
\text { stimulation }\end{array}$ \\
\hline 1 & $14, \mathrm{M}$ & Split cord & NB, MP & Successful & - & AH \\
\hline 2 & $2, \mathrm{~F}$ & Split cord, meningocele & - & Unsuccessful & - & - \\
\hline 3 & $13, \mathrm{~F}$ & Split cord, scoliosis & $\mathrm{NB}$ & Successful & - & AH \\
\hline 4 & $4, \mathrm{~F}$ & - & - & Successful & - & - \\
\hline 5 & $22, \mathrm{~F}$ & - & NB & Successful & - & - \\
\hline 6 & $3, \mathrm{~F}$ & Split cord & - & Unsuccessful & - & - \\
\hline 7 & $4, \mathrm{~F}$ & Split cord, meningocele & - & Successful & - & - \\
\hline 8 & $2, \mathrm{~F}$ & - & - & Successful & - & - \\
\hline 9 & $11, \mathrm{~F}$ & - & - & Successful & - & - \\
\hline 10 & $11, \mathrm{M}$ & Lipoma & MP & Successful & - & TA, PL \\
\hline
\end{tabular}

M: male, F: female, AH, abductor hallucis, EAS, external anal syphincter, TA: tibialis anterior, PL: peroneus longus, NB: neurogenic bladder, MP: mild paraparesis.

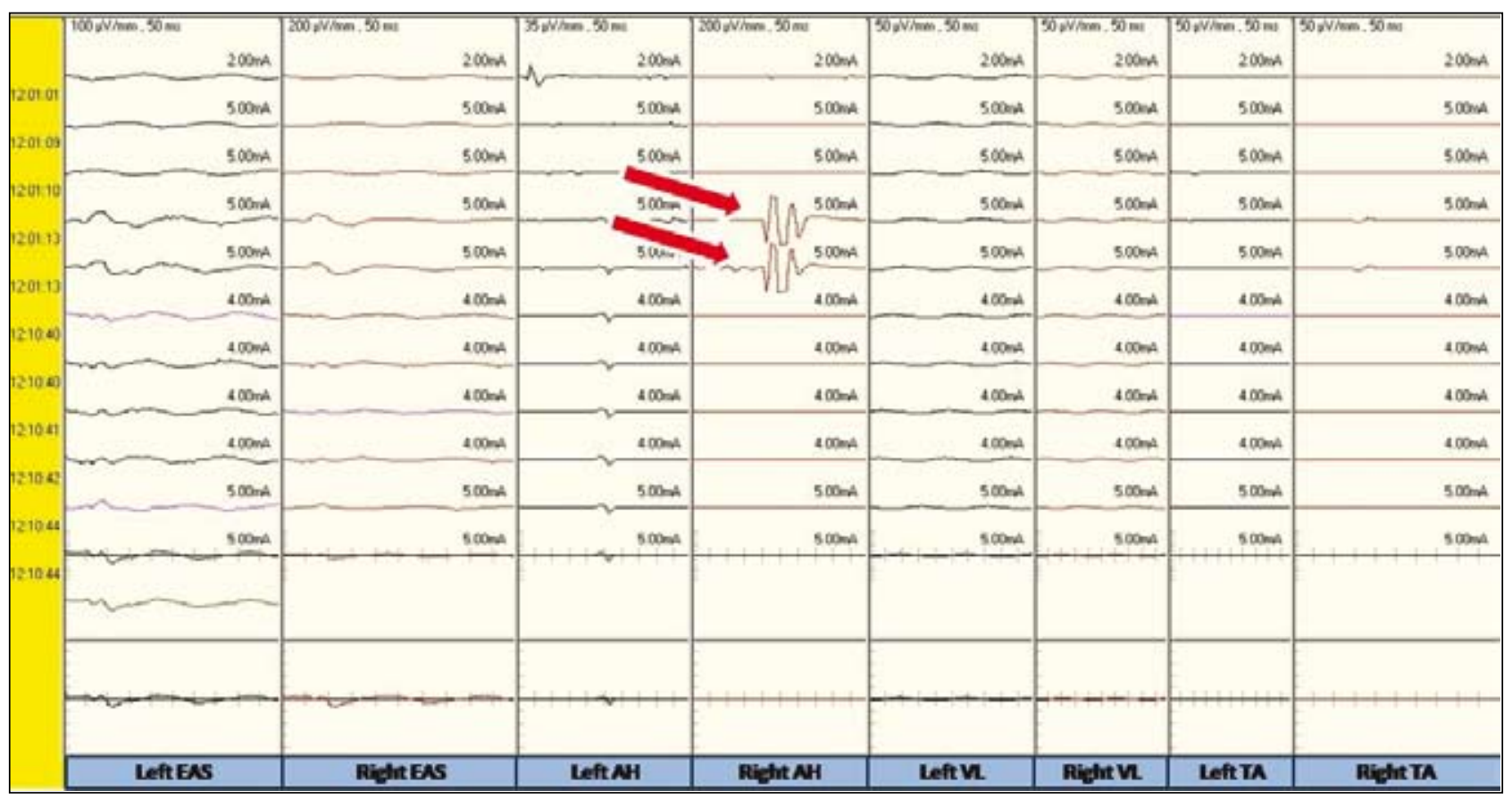

Figure 2: Motor responses from the right abductor hallucis muscle elicited by direct stimulation.

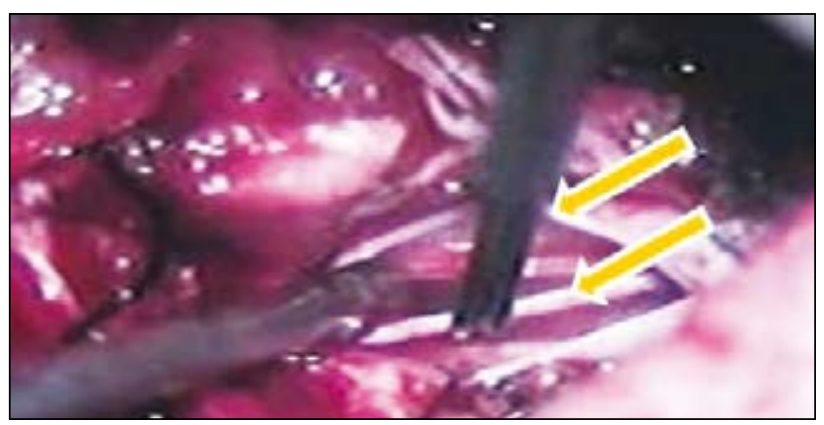

Figure 3: Direct stimulation of the suspected nerve tissue using a bipolar stimulator.

\section{DISCUSSION}

MIONM was used in the surgery of 10 cases with TCS. The surgical procedure was guided by the elicited responses especially via direct stimulation in all cases. Motor responses were noted in three cases by stimulation of functional nervous tissue. The responses elicited by direct stimulation are considered as the most important findings. MEP and SEP studies may show the abnormalities following injury, while direct stimulation provides information prior to the 
intervention, which enables the neurosurgeon to protect the nervous tissue. Free-run EMG may also show immediate signs of injury. However, the use of cautery usually interferes with the EMG signals.

Motor responses were elicited in three cases in this study. In one of the three cases, the nervous tissue was not evident before the motor response was elicited. The connective tissue was inspected more carefully and the rootlet was noted underneath the connective tissue. In the other two cases, the motor action potentials confirmed that the suspected tissue was of nervous structure.

Previous reports have emphasized the advantages of free-run EMG $(3,5,6,10)$. However, in our experience the usefulness of the free-run EMG is limited since cautery is used commonly throughout the surgery. This interference usually obscures all the signals. In addition, the IONM equipment usually has a selfprotection feature that closes the running tasks at that moment.

In previous reports, MEP studies were not usually in the primarily recommended IONM modalities for surgery of TCS $(3,5,10)$. Although MEP responses were not affected in any of our cases and there were no cases with additional neurological deficits, MEPs may be useful in detecting the injury of the motor fibers and supports other findings. Therefore, we think that the monitoring, follow-up and comparison of MEPs may provide significant information in addition to the other IONM modalities.

S2-4 myotomes were monitored by the electrodes placed in the EAS. However, it has been claimed that the monitoring of sacral myotomes alone with EAS recordings is inadequate and recording from the urethral sphincter was suggested (7). This may be achieved by ring electrodes adapted to a Foley catheter (5). However, we could not implement this method due to the shortage of equipment. In addition, the bulbocavernous reflex and penile/clitoral SEP studies have been recommended for the monitoring of TCS surgery (5). However, there is no agreement on a definite guide of IONM for TCS surgery due to the lack of studies with a higher number of cases. In one case, we monitored the function of the detrusor muscle by a Foley catheter indirectly, which may be an easy alternative method for monitoring the sacral segments especially those involved with urinary function.

\section{CONCLUSION}

Direct nerve root/rootlet stimulation should be one of the components of MIONM during surgery for the tethered cord syndrome to prevent postoperative neurological deficits.

\section{REFERENCES}

1. Ammerman JM, Kerr PB, Jarrell ST, Caputy AJ: A novel technique for the intraoperative monitoring of detrusor activity in intradural lesions of the cauda equina. Technical note. Surg Neurol 68:269-271, 2007

2. Choux M, Lena G, Genitori L, Foroutan M: The surgery of occult spinal dysraphism. Adv Tech Stand Neurosurg 21: 183-238, 1994

3. Husain AM, Shah D: Prognostic value of neurophysiologic intraoperative monitoring in tethered cord syndrome surgery. J Clin Neurophysiol 26:244-247, 2009

4. Kanev PM, Nierbrauer KS: Reflections on the natural history of lipomyelomeningocele. Pediatr Neurosurg 22:137-140, 1995

5. Khealani B, Husain AM: Neurophysiologic intraoperative monitoring during surgery for tethered cord syndrome. J Clin Neurophysiol 26:76-81, 2009

6. Kothbauer KF, Deletis V: Intraoperative neurophysiology of the conus medullaris and cauda equina. Childs Nerv Syst 26:247-253, 2009

7. Krassioukov AV, Sarjeant $\mathrm{R}$, Arkia $\mathrm{H}$, et al: Multimodality intraoperative monitoring during complex lumbosacral procedures: indications, techniques, and long-term followup review of 61 consecutive cases. J Neurosurg Spine 2004:1: 243-253

8. Lew SM, Kothbauer KF: Tethered cord syndrome: An updated review. Pediatr Neurosurg 43:236-248, 2007

9. Pang D, Wilberger JE: Tethered cord syndrome in adults. J Neurosurg 57:32-47, 1982

10. Paradiso G, Lee GY, Sarjeant R, Hoang L, Massicotte EM, Fehlings MG: Multimodality intraoperative neurophysiologic monitoring findings during surgery for adult tethered cord syndrome: Analysis of a series of 44 patients with long-term follow-up. Spine (Phila Pa 1976) 31:2095-2102, 2006

11. Pierre-Kahn A, Zerah M, Renier D, Cinalli G, Sainte-Rose C, Lellouch-Tubiana A, Brunelle F, Le Merrer M, Giudicelli Y, Pichon J, Kleinknecht B, Nataf F: Congenital lumbosacral lipomas. Childs Nerv Syst 13:298-335, 1997

12. Sala F, Krzan MJ, Deletis V: Intraoperative neurophysiological monitoring in pediatric neurosurgery: why, when, how? Childs Nerv Syst 18:264-287, 2002

13. Soonawala N, Overweg-Plandsoen WC, Brouwer OF: Early clinical signs and symptoms in occult spinal dysraphism: A retrospective case study of 47 patients. Clin Neurol Neurosurg 101:11-14, 1999 